\title{
Productivity of Rhizomes and Starch Quantification in Cultures of Different Vegetative Propagules of Arrowroot
}

\author{
Douglas C. de Souza ${ }^{1}$, Paula A. Costa ${ }^{1}$, Luis F. L. e Silva ${ }^{1}$, Thiago S. Guerra ${ }^{1}$, Luciane V. Resende ${ }^{1}$ \\ \& Joelma Pereira ${ }^{1}$ \\ ${ }^{1}$ Universidade Federal de Lavras, Lavras, MG, Brazil \\ Correspondence: Douglas C. de Souza, Universidade Federal de Lavras, Campus Universitário, 37200-000, \\ Lavras, MG, Brazil. Tel: 55-35-99113-6312. E-mail: douglascorrea@ymail.com
}

Received: January 22, 2019

Accepted: February 28, 2019 Online Published: April 15, 2019

doi:10.5539/jas.v11n5p419

URL: https://doi.org/10.5539/jas.v11n5p419

\begin{abstract}
Arrowroot rhizomes are rich in carbohydrate and are commonly grown by family farmers who have an important source of income in this activity and play a prominent role in the conservation of the species. There are few studies on the phytotechnical aspects of culture. The objective of this work was to evaluate the productive capacity of the 'common' arrowroot using different sizes and forms of propagation, aiming at the production of rhizomes and arrowroot starch, in different agricultural crops. The experimental design was the randomized block in a $4 \times 2$ factorial scheme, with 6 replicates. Four types of rhizome propagation (rhizomes-seeds of small size with a weight of 20 to $30 \mathrm{~g}$; rhizomes-seeds of average weight between 30.01 to $45 \mathrm{~g}$; rhizomes-seeds of large size weighing between $45.01 \mathrm{a} 60 \mathrm{~g}$, and seedlings produced in tissue culture), in two agricultural years (2015/2016 and 2016/2017). The variables total production, number of rhizomes, extraction yield and total starch production were evaluated. The type of propagule used interfered in the yield of rhizomes ( 9.85 to $\left.34.75 \mathrm{t} \mathrm{ha}^{-1}\right)$ and in the production of arrowroot starch (1.76 to $\left.7.68 \mathrm{t} \mathrm{ha}^{-1}\right)$. The vegetative propagation with pieces of rhizomes-seeds between 20 and $60 \mathrm{~g}$ was more viable than the micropropagation technique. Although the soil and climate conditions showed differences between the agricultural crops studied, they did not significantly influence the yield of rhizomes and arrowroot starch, by the type of propagule used.
\end{abstract}

Keywords: Maranta arundinacea L., unconventional vegetables, tissue culture, family farming

\section{Introduction}

Arrowroot (Maranta arundinacea L.) is a tropical South American crop with starch valued in the international market for its quality as a food ingredient. The literature shows that this starch can be used in the production of a paste of higher lightness and higher digestibility it can be used in the diet of celiac by the absence of gluten and as a potential source of prebiotics, therefore, it is recommended for fine confectionery, an application sector that competes with commercially modified starches. However, the shortage of arrowroot starch in the market induces a price increase and favors the occurrence of fraud through the substitution of commercial cassava starch (Jyothi et al., 2010; Kumalasari et al., 2012; Guilherme et al., 2019).

The rescue of the species is of extreme relevance, mainly for family agriculture, due to the rusticity of the plants that do not require very sophisticated technologies for the cultivation (Barbosa et al., 2015). However, due to the diffusion of knowledge about the topic, it is imperative to study the basic management and post-harvest techniques of arrowroot for starch production (Souza et al., 2017; Moreno et al., 2017).

In Brazil, the culture is propagated from whole rhizomes or the ends of the same. The commercial production of arrowroot is carried out by asexual (vegetative) or clonal propagation, being this technique feasible to maintain the characteristics of the matrix plant, to allow uniformity in the seedlings, to produce high quality food and to reduce the cost of production (Chagas et al., 2008; Hartmann, 2002).

However, the lack of planting material is one of the limiting factors for the expansion of vegetative propagated crops, making efficient use of seedlings necessary (Zárate et al., 2006; Torales et al., 2015). There are few studies on several aspects of the seedlings, but these deserve attention because the type and quality of the planting material determine differences in the speed of rooting, growth, and, consequently, the production and 
extension of the vegetative cycle (Zárate et al., 2006). Arrowroot is a long cycle crop, and it is indispensable to know the most viable type and size of the seedling (Zárate \& Vieira, 2005).

Despite the advantages, some problems such as the difficulty of conservation of planting material, the spread of pests and diseases, small multiplicative capacity, the difficulty of virus elimination, the lack of stand uniformity of the in the plantations and the risk of pests introduction of and diseases in the exchange of germplasm (Lameira et al., 2000; CID, 2017). In tissue culture is a strategy that allows the rapid multiplication of the material to be propagated from a single individual, and can be done at any time of the year, allowing a greater control over the sanity of the material, and this technique is important because it can be used for the production of endangered native species (Campos et al., 2013; Thakur \& Karnosky, 2007). With micropropagation it is possible to maximize the quality and uniformity of the plantations when selected genotypes are used (Moura et al., 2012).

In view of the above, the aim of this work was to evaluate the productive capacity of the 'common' arrowroot variety using different sizes and forms of propagation, aiming at the production of rhizomes and arrowroot starch, in different agricultural crops.

\section{Materials and Methods}

The experiments were conducted in the experimental area of the Olericultura Sector of the Department of Agriculture of the Federal University of Lavras (UFLA), in the city of Lavras, southern Minas Gerais state, with latitude $21^{\circ} 14^{\prime} \mathrm{S}$ and longitude $45^{\circ} 00^{\prime} \mathrm{W}$; at altitude of $918.8 \mathrm{~m}$. The climate of the region, according to the climatic classification of Köppen, is considered as Subtropical highland climate, with dry winter and rainy summer (Álvares et al., 2013).

Rhizomes of the 'common' variety, from the collection of Germplasm of Non-Conventional Vegetables of UFLA, were used. The following factors were considered in the experiments: production of arrowroot from different types of propagation (four specific categories studied: plants produced by small-seeded rhizomes-arrowroot seeds weighing 20 to $30 \mathrm{~g}$; medium-sized seed rhizomes with weight between 30.01 to $45 \mathrm{~g}$, rhizomes-seed of large size weighing between 45.01 to $60 \mathrm{~g}$, and seedlings produced in tissue culture); between different agricultural years (2015/2016 and 2016/2017), under a $4 \times 2$ factorial scheme, with 6 replicates.

To produce the seedlings in tissue culture the assay was carried out in the Plant Tissue Culture Laboratory of the UFLA Department of Agriculture, where it was established in vitro from the culture of shoot apices extracted from the arrowroot rhizomes. The explants were inoculated in MS culture medium (Murashige \& Skoog, 1962), supplemented with $9.0 \mu \mathrm{M}$ 6-benzylaminopurine (BAP) plus $30 \mathrm{~g} \mathrm{~L}^{-1}$ sucrose, solidified with $5.5 \mathrm{~g} \mathrm{~L}^{-1}$ of agar and $\mathrm{pH}$ adjusted to 5.8 before autoclaving $\left(121^{\circ} \mathrm{C}\right.$ for 20 minutes). The cultures were maintained in a growth room with a temperature of $27 \pm 1{ }^{\circ} \mathrm{C}$, under $35 \mu \mathrm{mol} \mathrm{m} \mathrm{m}^{-2} \mathrm{~s}^{-1}$ of light intensity from cold white lamps with a photoperiod of 16 hours/day, for 30 days. After in vitro development, the seedlings were kept in a greenhouse with nebulization and controlled temperature for acclimatization.

For the first experiment (first crop year), seedlings were produced in polyethylene bags $\left(5,292 \mathrm{~cm}^{3}\right)$ filled in the proportion of $60 \%$ Rohrbacher ${ }^{\circledR}$ commercial substrate (organic compounds, pine bark, and vermiculite), 30\% sifted land and $10 \%$ of sand. The polyethylene bags were kept in a greenhouse until the transplanting occurred approximately 60 days after planting when the seedlings presented four definitive leaves. In this initial period, the seedlings were irrigated by spraying, in order to keep the soil always moist during the budding phase until the plants reach around $20 \mathrm{~cm}$.

The materials from the first experiment were planted in December 2015 and transplanted to the field in February 2016 and harvested in September 2016. The experimental design was a randomized complete block (DBC) with six replications, each plot having eight plants, in which the floor area was composed of four central plants.

The spacing adopted in the experiments was $40 \mathrm{~cm}$ between rows and $50 \mathrm{~cm}$ between plants, resulting in a density of 50,000 ha- ${ }^{-1}$ plants (Souza et al., 2018). The soil of the experimental area was classified as a Red Dystroferric Latosol and had the following characteristics in the arable layer from 0 to $20 \mathrm{~cm}$ : $\mathrm{pH}\left(\right.$ in $\left.\mathrm{H}_{2} \mathrm{O}\right)=6.1$; Al exchangeable $=0.10 \mathrm{cmol} \mathrm{dm}{ }^{-3} ; \mathrm{Ca}^{2+}=1.80 \mathrm{cmol} \mathrm{dm}^{-3} ; \mathrm{Mg}^{2+}=0.60 \mathrm{cmol} \mathrm{dm}{ }^{-3} ;$ P-Mehlich $=2.60 \mathrm{mg} \mathrm{dm}^{-3}$; $\mathrm{K}^{+}=50 \mathrm{mg} \mathrm{dm}{ }^{-3}$; Organic matter $=2.61 \mathrm{dag} \mathrm{Kg}^{-1} ; \mathrm{V}=54.84 \%$; Sum of bases $=2.53 \mathrm{cmol} \mathrm{dm}^{-3} ; \mathrm{CTC}=4.61$ $\mathrm{cmol} \mathrm{dm}{ }^{-3} ; \mathrm{Zn}^{2+}=1.22 \mathrm{mg} \mathrm{dm}{ }^{-3} ; \mathrm{Fe}^{2+}=69.81 \mathrm{mg} \mathrm{dm}{ }^{-3} ; \mathrm{Mn}^{2+}=17.49 \mathrm{mg} \mathrm{dm}{ }^{-3} ; \mathrm{Cu}^{2+}=0.64 \mathrm{mg} \mathrm{dm}^{-3} ; \mathrm{B}=0.43$

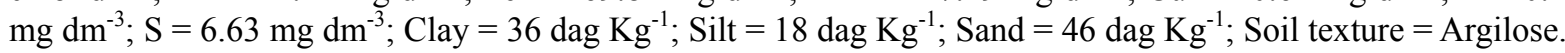

The soil preparation was done in a conventional way with plowing and two harrows and the beds were raised with the aid of rotoencerator in the dimensions of 1.25 meters of width by 0.25 meters of height. Based on the soil chemical analysis, the liming of the experiments were performed using $0.24 \mathrm{t} \mathrm{ha}^{-1}$ of limestone, as well as the fertilization of planting, incorporated into the pit, and 75 days after planting the cover fertilization, which 
was distributed close to the plant with superficial incorporation, according to recommendations adapted for tuberoses (Ribeiro et al., 1999). The fertilizers used were ammonium sulphate $(18 \% \mathrm{~N})$, simple superphosphate $\left(18 \% \mathrm{P}_{2} \mathrm{O}_{5}\right)$, and potassium chloride $\left(60 \% \mathrm{~K}_{2} \mathrm{O}\right)$. The cultural dealings were made according to the need of the crop, such as weeding, drip irrigation, fighting ant cutters and heaps.

The first experiment was harvested at 223 days after transplanting. The agronomic variables were evaluated: total yield $\left(\mathrm{t} \mathrm{ha}^{-1}\right)$ and the number of rhizomes (plant ${ }^{-1}$ unit). The rhizomes of each treatment were taken to the Laboratory of Grains, Roots and Tubers of the Department of Food Science of UFLA, for the extraction of starch. Arrowroot rhizomes were washed for the purpose of removing adhered soil and unnecessary parts and then selected for lack of insults and deformation. Afterward, they were cut into $0.5 \mathrm{~cm}$ thick slices and weighed. The experimental design was completely randomized (DIC), with three replicates for each treatment.

After the harvest, the rhizomes were processed, since the commercial product is the starch. In order to extract the starch, the rhizomes of each treatment were weighed and crushed with distilled water, 1:1, in an industrial blender (Lucre, model C4, Brazil), and then filtered in organza cloth. The suspension was rested ( \pm 16 hours) in a refrigerated environment $\left( \pm 5^{\circ} \mathrm{C}\right)$. The supernatant was discarded and the precipitated starch was resuspended with distilled water, to be discarded again. This starch suspension and the settling procedure were repeated until the product had starch characteristic color and texture. The material was pre-dried in a forced air circulation oven at $45^{\circ} \mathrm{C}$ for 24 hours and cooled to room temperature. Afterward, it was reduced to powder, using gral and pistil, sieved in a $0.350 \mathrm{~mm}$ sieve and, finally, packed in a vial until its subsequent use (Daiuto \& Cereda, 2003). The extraction yield (EY) was determined by the equation,

$$
\text { Extraction yield }[E Y](\%)=\frac{\text { Weight of starch extracted }(\mathrm{g})}{\text { Crushed rhizome weight }(\mathrm{g})} \times 100
$$

After harvesting the 2015/2016 crop experiment, the collected materials from the borders of each treatment were used as seed rhizomes to replant the new experiment in 2016/2017, and rhizomes-seeds were selected according to the size class of each treatment (small, medium and large) and planted directly in the field. At the beginning of November 2016, there was sprouting of the arrowroot rhizomes, and a thinning was necessary according to the spacing of $40 \times 50 \mathrm{~cm}$. Each parcel was composed of eight plants and the floor area by four central plants. The second experiment was harvested in July 2017 with 268 days after sprouting and the production, rhizome amount and extraction yield of arrowroot were also evaluated.

The results were analyzed with observations of means and standard deviation, and the means were submitted to analysis of variance (ANOVA). The averages were compared by the Tukey's test (1953) with the aid of SISVAR ${ }^{\circledR}$ software (Ferreira, 2011).

\section{Results and Discussion}

The analysis of variance shows that the productivity of arrowroot rhizomes was influenced by the type of propagules and the year of production $(p<0.05)$, however, there was no interaction between the factors studied $(p>0.05)$. According to Table 1, it can be observed that the types of seedlings produced by rhizomes-seeds of small, medium and large size did not present a significant difference between the different harvests, with a mean yield of $27.20( \pm 10.68) \mathrm{t} \mathrm{ha}^{-1}, 26.35( \pm 4.63) \mathrm{t} \mathrm{ha}^{-1}$ and $25.83( \pm 1.21) \mathrm{t} \mathrm{ha}^{-1}$, respectively. Regarding the agricultural production year, the $2016 / 2017$ harvest was the most productive with $26.61( \pm 8.19) \mathrm{t} \mathrm{ha}^{-1}$, while the harvest of 2015/2016 presented lower productivity, about $27 \%$, with an average of $19.39( \pm 6.72) \mathrm{tha}^{-1}$.

Table 1 . The productivity of arrowroot rhizomes produced in different types of propagation

\begin{tabular}{llll}
\hline \multirow{2}{*}{ Type of propagation } & \multicolumn{3}{c}{ Safflower crop $\left(\mathrm{t} \mathrm{ha}^{-1}\right)$} \\
\cline { 2 - 4 } & $2015 / 2016$ & $2016 / 2017$ & Averages \\
\hline Large rhizomes & 24.97 & 26.68 & $25.83 \mathrm{a}$ \\
Average rhizomes & 23.07 & 29.62 & $26.35 \mathrm{a}$ \\
Small rhizomes & 19.64 & 34.75 & $27.20 \mathrm{a}$ \\
Tissue culture & 9.85 & 15.38 & $12.62 \mathrm{~b}$ \\
- Averages & $19.39 \mathrm{~B}$ & $26.61 \mathrm{~A}$ & $\mathrm{CV}=29.68 \%$ \\
\hline
\end{tabular}

Note. Means followed by the same lowercase letters in the columns and uppercase letters in the lines do not differ according to the Tukey test at $5 \%$ probability. 
The climatic conditions during the development of the experiments are presented in Figure 1. The environment during the 2016/2017 experiment presented higher precipitation and temperature when compared to the previous harvest (2015/2016). The environmental conditions decisively influence the development of plants and the production of crops. The understanding of the factors involved, especially those of agroclimatic nature, is essential for the success of the commercial practice (Filgueira, 2013; Silva et al., 2018). The high temperature, up to certain limits, positively influences the rate of plant metabolism, while the sensitivity to photoperiod may modify its response (Taiz et al., 2017).

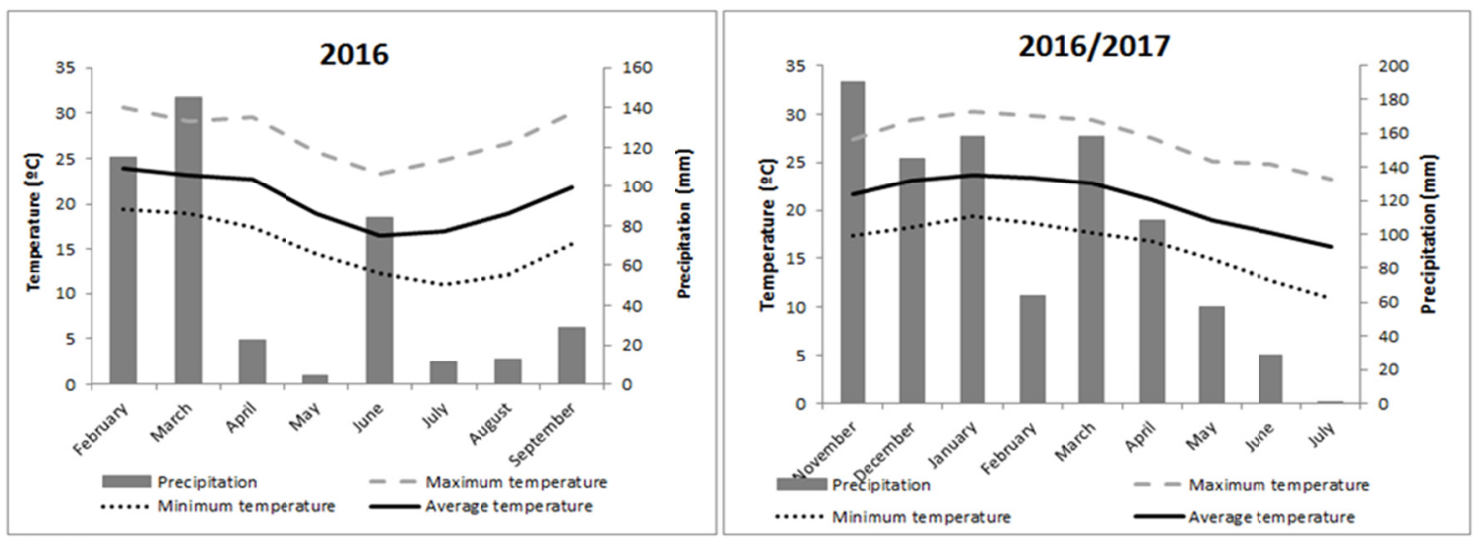

Figure 1. Climatic data of the Meteorological Station of the Federal University of Lavras during the experiments field in 2016 to 2017

The number of rhizomes produced per plant presented a significant difference only for the fact type of propagation and there was no interaction between the factors $(p>0.05)$. The plants produced in tissue culture had a mean of $6.54( \pm 0.76)$ rhizomes plant ${ }^{-1}$, while the plants propagated by different sizes of rhizomes-seeds showed no differences between them, with a mean of $12.18( \pm 0.62)$ rhizomes plant ${ }^{-1}, 46 \%$ higher than that observed with the micropropagation technique (Table 2).

Table 2. The number of arrowroot rhizomes produced in different types of propagation

\begin{tabular}{llll}
\hline \multirow{2}{*}{ Type of propagation } & \multicolumn{2}{c}{ Safflower crop (rhizomes plant ${ }^{-1}$ ) } \\
\cline { 2 - 4 } & $2015 / 2016$ & $2016 / 2017$ & Averages \\
\hline Large rhizomes & 12.42 & 12.20 & $12.31 \mathrm{a}$ \\
Average rhizomes & 12.13 & 11.10 & $11.61 \mathrm{a}$ \\
Small rhizomes & 12.21 & 13.00 & $12.60 \mathrm{a}$ \\
Tissue culture & 7.08 & 6.00 & $6.54 \mathrm{~b}$ \\
\hline Averages & $10.95 \mathrm{~A}$ & $10.57 \mathrm{~A}$ & $\mathrm{CV}=24.50 \%$ \\
\hline
\end{tabular}

Note. Means followed by the same lowercase letters in the columns and uppercase letters in the lines do not differ according to the Tukey test at $5 \%$ probability.

The higher productivity and number of rhizomes observed during the two harvests as a consequence of the different types of propagation showed that the amount of reserve present in the rhizome seeds increased the probability of success in the production of seedlings, since it allows survival over a longer period of time under conditions environmental impacts (Monteiro \& Peressin, 1997; Berni et al., 2014). This fact corroborates the study carried out by Zárate and Viera (2005), who observed higher yields of rhizomes in arrowroot plants from larger propagules (in this study, only rhizomes of 3.7 to $16.7 \mathrm{~g}$ ) were considered. Research by Silva et al. (2011), working with Xanthosoma mafaffa production according to the type of rhizomes-seeds, also concluded that the highest yields were obtained from rhizomes-seeds larger.

After the processing of the arrowroot rhizomes for starch production, the yield values were observed. According to the analysis of variance, this variable was influenced by the agricultural harvest, the type of propagation and the interaction of these factors $(p<0.05$ ). According to the statistical breakdown (Table 3), the 2016/2017 
harvest had the highest yield in each type of propagation when compared to the harvest of 2015/2016. When showing the type of propagation in each crop, it is observed that in 2015/2016 the rhizomes-seeds of avarage size presented higher yield, followed by the yield presented by rhizomes-seeds of large and produced in tissue culture. In the next harvest, the yield of starch was higher in plants produced by rhizomes-seeds of large and medium size.

Table 3. Extraction yield (EY) in different types of propagation

\begin{tabular}{llcc}
\hline \multirow{2}{*}{ Type of propagation } & \multicolumn{2}{c}{ Safflower crop (g extracted starch per 100 g ground rhizome) } \\
\cline { 2 - 4 } & $2015 / 2016$ & $2016 / 2017$ & Averages \\
\hline Large rhizomes & $18.37 \mathrm{bB}$ & $23.63 \mathrm{aA}$ & 21.00 \\
Average rhizomes & $19.15 \mathrm{aB}$ & $23.32 \mathrm{aA}$ & 21.24 \\
Small rhizomes & $16.96 \mathrm{cB}$ & $22.10 \mathrm{bA}$ & 19.53 \\
Tissue culture & $17.82 \mathrm{bB}$ & $20.93 \mathrm{cA}$ & 19.83 \\
\hline Averages & 18.07 & 22.50 & $\mathrm{CV}=2.40 \%$ \\
\hline
\end{tabular}

Note. Means followed by the same lowercase letters in the columns and uppercase letters in the lines do not differ according to the Tukey test at $5 \%$ probability.

In practical terms for the producer, the production of starch per unit area is fundamental to the success of the enterprise. In this experiment, the production of arrowroot starch area was influenced by the type of propagules and the year of production $(p<0.05)$, however, there was no interaction between the factors studied $(p>0.05)$. In the two evaluated crops, the plants produced by rhizomes-seeds of large, medium and small size are statically equal, with a mean starch production by area in 2015/2016 of $4.11( \pm 0.68) \mathrm{t} \mathrm{ha}^{-1}$ and in 2016/2017 of 6.96 $( \pm 0.69) \mathrm{t} \mathrm{ha}^{-1}$. The production of $2016 / 2017$ stood out in all treatments when compared to the previous harvest (Table 4).

Table 4. Production of arrowroot starch per unit area, obtained by different types of propagation

\begin{tabular}{llll}
\hline \multirow{2}{*}{ Type of propagation } & \multicolumn{2}{l}{ Safflower crop } & \\
\cline { 2 - 4 } & $2015 / 2016$ & $2016 / 2017$ & Averages \\
\hline Large rhizomes & 4.59 & 6.29 & $5.50 \mathrm{a}$ \\
Average rhizomes & 4.42 & 6.92 & $5.67 \mathrm{a}$ \\
Small rhizomes & 3.33 & 7.68 & $5.51 \mathrm{a}$ \\
Tissue culture & 1.76 & 3.22 & $2.49 \mathrm{~b}$ \\
\hline Averages & $3.52 \mathrm{~B}$ & $6.03 \mathrm{~A}$ & $\mathrm{CV}=31.49 \%$
\end{tabular}

Note. Means followed by the same lowercase letters in the columns and uppercase letters in the lines do not differ according to the Tukey test at $5 \%$ probability.

In order to evaluate the productivity of stout arrowroots in different phytotechnical conditions, Souza et al. (2018), however, propagated by rhizomes-seeds of 30 to $60 \mathrm{~g}$, obtained in the most productive treatments an average of $6.43( \pm 1.49) \mathrm{t} \mathrm{ha}^{-1}$ of arrowroot starch, similar to the agricultural year $2016 / 2017$ in vegetative propagated material.

\section{Conclusion}

The type of propagule used interfered in the yield of rhizomes and arrowroot starch. The vegetative propagation, through rhizomes-seeds between 20 and $60 \mathrm{~g}$, was more feasible than the micropropagation technique.

Although soil and climate conditions show differences between the agricultural crops studied, these did not significantly influence the yield of rhizomes and arrowroot starch by the type of propagule used.

\section{Acknowledgements}

The authores thank the Fundação de Apoio à Pesquisa de Minas Gerais (FAPEMIG), the Coordenação de Aperfeiçoamento de Pessoal de Nível Superior (CAPES), and the Conselho Nacional de Desenvolvimento Científica e Tecnológico (CNPq), for financial support and scholarships. 


\section{References}

Álvares, C. A., Stape, J. L., Sentelhas, P. C., Goncalves, J. L. M., \& Sparovek, G. (2013). Koppen's climate classification map for Brazil. Meteorologische Zeitschrift, 22, 711-728. https://doi.org/10.1127/0941-2948/ 2013/0507

Barbosa, J. C. V., Colombo, J. N., Puiatti, M., Cecon, P. R., \& Silvestre, H. C. (2015). Performance of arrowroot 'Viçosa' intercropped with sunnhemp. Revista Brasileira de Ciências Agrárias, 10, 518-523.

Berni, R. F., Chaves, F. C. M., Pinheiro, J. B., \& Vaz, A. P. A. (2014). Influence of the weight of seed-rhizomes in the production of turmeric. Revista Brasileira de Plantas Medicinais, 16, 765-770. https://doi.org/ 10.1590/1983-084x/11_167

Campos, V. C. A., Lima-Brito, A., Gutierrez, I. E. M. D., Santana, J. R. F. D., \& Souza, A. V. V. D. (2013). Micropropagation of umburana de cheiro. Ciência Rural, 43, 639-644. https://doi.org/10.1590/S0103 $-84782013005000018$

Cid, L. P. B. (2017). Cultivo in vitro de plantas (3rd ed., p. 325). Embrapa, Brazil.

Chagas, J. H., Pinto, J. E. B. P., Bertolucci, S. K. V., \& Nalon, F. H. (2008). Scion production of mint in function of age and different types of cutting. Ciência Rural, 38, 2157-2163. https://doi.org/10.1590/S010384782008000800011

Daiuto, E. R., \& Cereda, M. P. (2003). Amido como suporte na desidratação por atomização e em microencapsulamento. In M. P. Cereda, \& O. F. Vilpoux (Eds.), Tecnologia, usos e potencialidades de tuberosas amiláceas sul americanas (pp. 449-475). São Paulo: Fundação Cargill.

Ferreira, D. F. (2011). Sisvar: A computer statistical analysis system. Ciência e Agrotecnologia, 35(6), 1039-1042. https://doi.org/10.1590/S1413-70542011000600001

Filgueira, F. A. R. (2013). Novo manual de olericultura: Agrotecnologia moderna na produção e comercialização de hortaliças (p. 421). Universidade Federal de Viçosa: Empresa Júnior de Agronomia.

Guilherme, O. D., Branco, F. P., Madeira, N. R., Brito, V. H., Oliveira, C. E., Jadoski, C. J., \& Cereda, M. P. (2019). Starch valorization from corm, tuber, rhizome, and root crops. Starches for Food Application, 167-222. https://doi.org/10.1016/B978-0-12-809440-2.00005-8

Hartmann, H. T. (2002). Hartmann and Kester's plant propagation: Principles and practices. Prentice Hall, Upper Saddle River, NJ.

Jyothi, A. N., Sajeev, M. S., \& Sreekumar, J. N. (2010). Hydrothermal modifications of tropical tuber starches. 1. Effect of heat-moisture treatment on the physicochemical, rheological and gelatinization characteristics. Starch-Stärke, 62, 28-40. https://doi.org/10.1002/star.200900191

Kumalasari, I. D., Hamayani, E., Lestari, L. A., Raharjo, S., Asmara, W., Nishi, K.; \& Sugahara, T. (2012) Evaluation of immune stimulatory effect of the arrowroot (Maranta arundinacea. L.) in vitro and in vivo. Cytotechnology, 64, 131-137. https://doi.org/10.1007/s10616-011-9403-4

Monteiro, D. A., \& Peressin, V. A. (1997). Efeito do tamanho do rizoma-semente, da época e do local de plantio, na produção de rizomas de mangará. Bragantia, 56, 155-161. https://doi.org/10.1590/S0006-870519970001 00016

Moreno, L. B., Torales, E. P., Heid, D. M., Zárate, N. A. H., \& Abrão, M. S. (2017). Influence of plant density and hilling on yield and profitability of arrowroot. Pesq. Agropec. Trop., 47, 465-471. https://doi.org/10. 1590/1983-40632017v4748643

Moura, L. C., Titon, M., Fernandes, J. S. C., Santana, R. C., \& Oliveira, M. L. R. (2012). Micropropagação de sucupira-preta por meio de gemas axilares. Pesquisa Agropecuária Brasileira, 47, 1691-1698. https://doi.org/10.1590/S0100-204X2012001200003

Murashige, T., \& Skoog, F.A. (1962). A revised medium for rapid growth and bioassays with tobacco tissue cultures. Physiologia Plantarum, 15, 473-497. https://doi.org/10.1111/j.1399-3054.1962.tb08052.x

Lameira, O. A., Lemos, O. F., Menezes, I. C., \& Pinto, J. E. B. P. (2000). Cultura de tecidos (manual) (p. 42). Embrapa, Brazil.

Ribeiro, A. C., Guimarães, P. T. G., \& Alvarez, V. H. (1999). Recomendações para o uso de corretivos e fertilizantes em Minas Gerais: $5^{\circ}$ Aproximação (p. 322). Comissão de fertilidade do solo do estado de Minas Gerais. 
Silva, A. V., Silva, C. M., Pavan, B. E., Pessoa, W. R. L. S., \& Mielezrski, F. (2018). Época de semeadura x grupos de maturação nos componentes de rendimentos de soja. Cultura Agronômica, 27, 44-56.

Silva, A. C., Júnior, C. F. C., \& Costa, C. A. (2011). Tannia yield in function of the size seed-rhizomes. Biosci. J., 27, 706-709.

Souza, D. C., Silva, L. F. L., Resende, L. V., Costa, P. A., Guerra, T. S., Gonçalves, W. M., \& Pereira, T. A. R. (2017). Conservação pós-colheita de araruta em função da temperatura de armazenamento. Magistra, 28, 403-410.

Souza, D. C., Silva, L. F. L., Resende, L. V., Costa, P. A., Guerra, T. S., \& Gonçalves, W. M. (2018). Influence of irrigation, planting density and vegetative propagation on yield of rhizomes of starch the arrowroot. Rev. Ciênc. Agr., 41, 683-691. https://doi.org/10.19084/RCA18015

Taiz, L., Zeiger, E., Moller, I., \& Murphy, A. (2017). Plant Physiology and Development (6th ed., p. 888). Porto Alegre: Artmed.

Thakur, R., \& Karnosky, D. (2007). Micropropagation and germplasm conservation of Central Park Splendor Chinese elm (Ulmus parvifolia Jacq.'A/Ross Central Park') trees. Plant Cell Reports, 26, 1171-1177. https://doi.org/10.1007/s00299-007-0334-7

Torales, E. R., Zárate, N. A. H., Vieira, M. C., Heid, D. M., Moreno, L. B., \& Grando, V. R. (2015). Productivity peruvian carrot in response to plant spacings and average masses of seedlings. Biosci. J., 31, 433-444.

Zárate, N. A. H., Vieira, M. C., Helmich, M., \& Maria, M. A. (2006). Size of seed-rhizomes and rows of plants on Comum tannia yield. Ciência e Agrotecnologia, 30, 907-913. https://doi.org/10.1590/S1413-70542006 000500013

Zárate, N. A. H., \& Vieira, M. C. (2005). Production of Comum arrowroot obtained from three types of propagul. Ciência e Agrotecnologia, 299, 995-1000. https://doi.org/10.1590/S1413-70542005000500012

\section{Copyrights}

Copyright for this article is retained by the author(s), with first publication rights granted to the journal.

This is an open-access article distributed under the terms and conditions of the Creative Commons Attribution license (http://creativecommons.org/licenses/by/4.0/). 